\title{
Early Childhood Character Education During the Covid Pandemic 19
}

\author{
Henni Anggraini*, Sarah Emmanuel H \\ Program Studi PG-PAUD \\ Universitas PGRI Kanjuruhan Malang \\ Malang, Indonesia \\ *hennianggraini@unikama.ac.id, sarahemmanuel@unikama.ac.id
}

\begin{abstract}
This Early childhood is often said to be the golden age, namely the basic period in the life of a child which will affect his life in the future. It was during this golden age that parents and teachers had a good opportunity to instill values in children. The inculcation of values can be done in two settings, namely the character education setting in the family and also the character education setting in school. Character education is very important, given the inevitable development of the era that will bring children into a generation whose character values are getting lower. Character education carried out from an early age aims to build a child's character, and continues throughout his life. During the Covid 19 pandemic, learning in children was carried out with assistance by parents so that family settings were the most important thing in cultivating character values in early childhood. Cultivating Moral Values in Early Childhood can be done by various methods, namely the Play Method, Storytelling Method, Assignment Method, and Conversation Method.
\end{abstract}

\section{Keywords—early childhood, character education}

\section{INTRODUCTION}

Education is the right of all Indonesian citizens. In Law No. 20 of 2003 concerning the National Education System (SISDIKNAS) which stated that "Early childhood education is a coaching effort aimed at children from birth until six years old, which is carried out through providing educational stimulus to help grow and develop physically and spiritually in order to children have readiness to enter further education".

Education aims to develop many aspects in children, specifically physical motor, cognitive and psycho-social aspects. One of the important aspects in early childhood development is instilling moral values that will establish their character when they are adults. Moral, namely understanding right and wrong, and that understanding causes changes in behavior [1]. In Freud's psychoanalytic theory [2] suggests that moral behavior is formed from infancy in the womb and early years of life. So, it is appropriate if it starts to form in early childhood with several strategies, likes by training and habituation, playing activities, and learning.

Education of character in early childhood has the aim of building the initial foundation to form character in accordance with the noble values of nation. This was accordance with John Locke's philosophical view, namely the tabula rasa theory which stated that children are born like white papers, where the environment has an important role in determining their character and personality as adults [1]. Environmental factors play an important role in behavior change.

An environmental setting in character formation in early childhood includes family and school environment settings. Schools with strong parental support for the value planting program will establish student's behavior according to the desired character. The forms of values taught in schools are the values of honesty, fairness, tolerance of self-discipline wisdom, helping to help, caring each other's, cooperation, courage and a democratic system [3]. In the school, teachers are tasked with instilling character values through lessons and modeling behavior. Teachers are important figures in schools because they are usually idol figures of children in the school. School integrated character education in learning through the development of activities and habituation [4].

However, corona virus or pandemic Covid-19 which began to spread in Indonesia since March 2020 has caused some social activities to be restricted. The government has even begun to assign every citizen to work from home, learn from home and pray at home. This has an impact in all aspects of people's lives, including the world of education in Indonesia. This is stated in the Minister of Education and Culture Circular Letter Number 4 of 2020 concerning the implementation of educational policies in the emergency period of the spread of the Corona virus Disease (Covid-19).

The circular regulates all policies in terms of education, one of them which is teaching and learning activities from home which are directed in the form of online / distance learning which was carried out to provide meaningful learning experiences for students. Some of the strategies taken by the government can certainly cause several problems in individual growth and development, especially in children. Social restrictions and closing schools can increase stress, anxiety, and depression in children [5]. The coronavirus disease (COVID-19) affected virtually all countries. Uncertain about the health risk and an increasing financial loss will contribute to widespread emotional distress and an increased risk of psychiatric disorders shortly. Posttraumatic, anxiety, and depression disorders are expected during and aftermath of the pandemic. Some groups, like children, have more susceptibility 
to having long term consequences in mental health [6]. To overcome this problem, parents and teachers must play a role and create an environment that continues to support children's growth and development even though they must continue to study at home to prevent the spread of covid-19.

Changes in learning that are carried out online at home cause a change in the role of parents, where parents are required to provide learning assistance directly from home. In families with more favorable socioeconomic conditions, children and caregivers need to adapt to a distance-learning model [7]. This requires participation of parents in supervising the development of their children, not only in the aspects of physical, motoric, cognitive development, but also socioemotional development, specifically in terms of instilling character values from the home, where parental behavior habits become role models for children.

Character comes from the Greek word "karasso" which means blueprint, basic format, and fingerprint. Meanwhile, Mounier Character is translated into two things, namely as a collection of conditions that are given just like that and as a desired process that will build in the future [8]. Character Education is a value education, character education, moral education, character education which aims to develop students abilities to make good and bad decisions, maintain what is good and realize that good in everyday life [9]. According to Ki Hadjar Dewantara 2013, a person's character is influenced by initial talent and subsequent teaching or education.

Kevin Ryan and Thomas Lickona [3] emphasized that there are 3 elements in character education, i.e.

- Moral definition is moral awareness, understanding of values, the ability to take ideas, moral rationality.

- Affections or elements of moral feelings include conscience (awareness of good and bad), one's selfesteem, empathy towards others, feelings of loving kindness, self-control and humility.

- Action and action: competence (having the ability to apply moral decisions and feelings to concrete actions.

\section{A. Moral Development}

1) Piaget focuses on aspects of how children think about moral issues by observing and interviewing groups of children aged 4-12 years who are involved in a game. Piaget concluded that children think about morality is divided into 2 stages, namely the heteronomous morality stage in children aged 4-7 years where they perceive rules as an environment that does not change and is out of human control. The second stage is children aged 10 years and over, where they realize that the rules and laws were created by humans.

2) 2.Lawrence Kolhberg developed a theory about the development of moral reasoning which is explored the structure of the thought processes involved in moral reasoning. The moral development is classified into three levels where each level consists of 2 stages, i.e. :
- Level 1: Pre-Conventional Moral Reasoning (covering the Punishment and Compliance orientation stages, and the Individualism Orientation and Instrumental Orientation stages).

- Level 2: Conventional Moral Reasoning (includes the Interpersonal Conformity Orientation stage and the Law and rules Orientation stage.

- Level 3: Post-Conventional moral reasoning (includes the social contract orientation stage and the universal ethical orientation stage)

\section{METHODS}

This study uses a library research method. It is a research method where data collection is based on literature in the form of books and journals, magazines, newspapers etc. The analysis technique used in this research is the content analysis technique in which the researcher carries out the selection process, compares, and combines the data obtained. So, the relevant discussion results are obtained.

\section{RESULTS}

According to $\mathrm{Ki}$ Hadjar Dewantara [10], character is personality, which means human nature that is permanent and it becomes a special characteristic that distinguishes each individual. While character education is education that has the goal of helping children have desired strong character. Character education can be carried out based on the setting of a formal education environment, but seeing on pandemic Covid19 has caused the government to adopt a policy where learning is carried out from home with the assistance of parents. Based on the problems above, there are several characters that can be built during this pandemic in a family setting, namely independence, creativity, discipline and a sense of responsibility.

Character Education can be built in individuals from an early age. By seeing at this time, children are easily record every stimulus they get from the environment. Especially in the family environment which is the first and foremost place of learning for children. Character education in children must be adapted to the stages of development. In early childhood, where according to Kohlberg, they are still at the preconventional stage There are several strategies that parents can do for instilling moral values in order to establish children's character when they grow up, like the first is modeling, where parents are the role the main model for children, specifically when parents talk, behave, behave indirectly will be emulated by their children.

The second character education strategy is "teaching" where the teacher (at the school) communicates with parents to discuss together and arrange activities periodically to determine the moral values that will be formed through playing, role playing, telling stories, and singing.

The third character education strategy is through reinforcing the environment "reinforcing", that is by 
strengthening the character to be formed in the family environment. This reinforcement can be done by giving rewards such as gifts, praise, and attention which dedicated to children when they show good behaviors, but still discussing with children if bad behavior appears and explaining the reasons why it is considered bad.

\section{CONCLUSION}

Based on the description above, the authors draw the conclusion that character Education in early childhood, it must be adapted to the stages of moral development where parents must understand that children are at a pre-conventional stage, namely that children understand that good and bad behavior is adjusted to the rewards and punishments they get, character Education during pandemic covid-19 depends on the role of schools in collaborating to implement behavioral habituations with parental assistance at home, and the strategy for implementing family education can be carried out in three ways, such as modeling, teaching and reinforcing

\section{ACKNOWLEDGMENT}

The author would like to thank the University of Kanjuruhan Malang for supporting the author in conducting this research.

\section{REFERENCES}

[1] J.W. Santrock, Life span development: Perkembangan masa hidup. Jilid 2. Jakarta: Erlangga. 2013.

[2] M.J. Wantah, Pengembangan Disiplin dan Pembentukan Moral Pada Anak Usia Dini. Departemen Pendidikan Nasional Direktorat Pembinaan Pendidikan Tenaga Kependidikan dan Ketenagaan Perguruan Tinggi. 2005.

[3] T. Lickona, Educating For Character: Mendidik Untuk Membentuk Karakter. Bumi Aksara: Jakarta. 2019.

[4] A. Sobarna and A Hakim, "Management Character Education in Kindergarten". Indonesian Journal of Early Childhood Education Studies. 6(2), accessed by: 30 October 2020, 2017.

[5] L.A.d. Araújo, C.F. Veloso, M.d.C. Souza, c.J.M.C.d. Azevedo, and e.G. Tarrod, "The potential impact of the COVID-19 pandemic on child growth and development: a systematic review". Jurnal Pediatr.

[6] D.M.d. Miranda, B.d.S. Athanasio, A.C.S. Oliveira, A.C.Simoes-ESilva, "How is COVID-19 pandemic impacting mental health of children and adolescents?." International Journal of Disaster Risk Reduction (2020): 101845. 2020.

[7] G. Wang, Y. Zhang, J. Zhao, J. Zhang, F. Jiang, "Mitigate the effects of home confinement on children during the COVID-19 outbreak". Lancet. 2020; 395:945-947

[8] D. Koesoema, Tiga Matra Pendidikan Karakter. Majalah Basis, No.0708, Tahun ke 56, 2007

[9] Daryanto and S. Darmiatun, Pendidikan Karakter di Sekolah. Gava Meida: Yogyakarta. 2013.

[10] Suparno, Pendidikan Karakter di Sekolah. Kanisius: Yogyakarta. 2015. 